\title{
Student voice in Irish post-primary schools: is the challenge too challenging?
}

\author{
Domnall Fleming
}

School of Education, UCC

\section{Introduction}

All of us, as students, attended school and sat in classrooms for long periods. We listened (most of the time!), we absorbed, we learned, we sat and passed examinations (hopefully!), but we were largely silent participants in the whole classroom process. Yes, we answered and asked questions about what we were learning and responded to our teachers and classmates but, did anyone in our schools ever ask us what we thought about how we were being taught or whether and how we were learning? Did anyone ever ask us for our opinions on our schools or the classrooms in which we sat for all of that time? The answer is often a resounding no.

There is no tradition in Irish schools to ask, consult or discuss with students their views on their school, their classroom, their teachers, their learning or their experience in this very important and formative period of their lives. The challenge for schools therefore is why not engage with student voice?

\section{What is student voice?}

Student voice, as a term, can be explained at a number of levels. It is, at its most basic level, engaging the student in dialogue, discussion and communication in the classroom about the topics that they are learning. This can be seen in normal classroom interactions between the teacher and students as questioning, discussion, brainstorming, debating and presenting. This voice provides the teacher with an insight into how students are progressing and also provides for an active and engaging classroom.

At a deeper level, student voice also means 'having a say'. In this case, student voice refers to consultation and dialogue about experiences in the classroom and in the school as a whole. Students are asked and given the opportunity to express an opinion relating to their school and classroom experience. This student voice provides the teacher and the school with the students' perspectives and these could be used to understand and improve the school. In both of these situations, however, the student voice is largely directed and controlled by teachers. Students are asked or invited to 'have a say'. 
At an even deeper level, student voice is a process where students and teachers work together continually to research, examine and analyse what happens in schools and classrooms. This deeper process involves working together to co-construct learning and teaching in the classroom and students' experience of the school as a whole. This has the potential to transform the school and the classroom as it combines all the voices involved.

As we all know from our school days, our relationship with our teachers is vitally important to our learning and progress through school. Student voice can only exist when there are positive and open relationships between students and teachers. Some could argue though, that if students have a voice or a say that this will challenge the traditional power and authority of the teacher and therefore upset this relationship. Research shows that student voice enhances relationships at classroom and school level. Students respect their teachers because of the dialogue, communication and consultation that reflect student voice.

Student councils can be viewed as one element of student voice. They exist in most Irish post-primary schools and, as set out in the Education Act (1998) are structured to 'promote the interests of the school and the involvement of students in the affairs of the school'. Research suggests that representative student councils do involve students in the affairs of the school but, at a level that concerns issues like school uniform, the quality of food and facilities in the school, and the quality of the school environment. Student councils, as they currently exist, do not provide a forum for a deeper student voice to develop in schools.

\section{My research design}

This study uses qualitative and quantitative methods to research whether student voice in our post-primary schools can improve engagement, participation and learning. Three case-study schools from the voluntary secondary and vocational sectors were used in the research. Within these schools, the student councils were researched using observation, interviews and questionnaires. In parallel, nine teachers used student voice strategies in their classrooms with eighteen class groups across a range of subjects over a school year. All the students in these class groups completed questionnaires at both the beginning and end of the study period. Seventy students were interviewed in focus groups. The nine teachers completed reflective diaries and were interviewed on two occasions during the school year to examine their experience of student voice in the classroom.

Student voice strategies involved both teachers and their students engaging in a discussion and in the completion of a questionnaire relating to teaching and learning within the confines of their particular classroom relationship. The dialogue that this generated focused on pedagogy. While teachers initiated this dialogue, they listened carefully to their students and analysed the students' responses to the questionnaire. The teachers 
then modified their teaching and classroom practice based on what they considered reasonable, possible and constructive.

My doctoral research also applies the findings of student voice research from other countries to the Irish post-primary context. It reflects both the challenges and opportunities of student voice for schools. The outcomes of the research should inform the design of internal school self-evaluation processes, school and classroom planning and the wider school improvement agenda.

\section{The students' voice}

My study researched the student voice in both the classroom and, through the student council, at whole-school level. The initial analysis of the data gathered focused particularly on student voice in the classroom and the data clearly showed that students could think about and discuss their classroom experience and their learning in a meaningful way. They described what they liked and disliked, what they felt was effective and ineffective in class, and what helped them to learn.

Students were universally positive about their teachers and what happened in their class, but the clear message was that they wanted to be active and engaged in the classroom by a variety of methodologies and active-learning strategies. Questioning, both written and oral, work sheets, visual materials, practical work, and group and pair work were all cited by students as engaging, active and effective ways for them to understand and to learn. Co-operative learning involving groups or pairs of students was seen as very effective by students. Answering questions as a group rather than being 'put on the spot' by a direct question from their teacher was a regular response. The students also voiced the pace of learning, the positive classroom atmosphere and their relationship with their teacher as very significant in their engagement and participation in the classroom and in their learning.

Almost all students cited the delivery of lesson content through note-taking as a very negative learning experience. In one interview a student stated that

"It can get very boring and people lose concentration when loads of notes are just put up for us to write down. People would understand more if these notes were condensed into smaller bullet points and if they were explained by the teacher as people would understand better"

Pressure of time and what was perceived as 'rushing' to complete a topic were also seen as having negative influence in class. Good discipline and management in the classroom was expected and students stated that "if people are talking all the time" they find it very difficult to learn in class. 


\section{The teachers' voice}

Following the initial analysis of teachers' interviews and their reflective diaries, all expressed the view that engaging with student voice made them think and reflect on their teaching, on their students' learning and on their relationship with their classes. Student voice in the classroom was a new experience. While all were affirmed by what they heard and read, some were surprised and taken aback by what the students had said and the insights that they had.

Having engaged in dialogue with their students and having read the questionnaires, the teachers involved in the study made changes in their classrooms. Some teachers increased their use of visuals and introduced group and pair work, presentations by students, projects and a range of other student-centered methods. Others became more conscious of their use of notes and moved to shorter bulleted-type key points and linked this to shorter and more focused homework.

Some teachers did express reservations about what the students might actually say and if they would personalise any perceived criticisms. The initial analysis of the interviews and diaries clearly showed that this was not the case. The teachers were willing to change what they did in class in response to what the students had voiced to them. When asked if these changes improved the students' learning, one teacher commented in a diary response:

"From correction of write-ups it is becoming increasingly evident that by active participation in class, group and class discussion and peer questioning, their own written work has improved greatly".

Another said, "They really became more interested and involved. The group work was very good but now they have become very familiar with it and in asking each other questions rather than me doing it all the time".

Another teacher, interestingly, is very positive about the changes in the students, but is concerned about the examination looming in the background,

"Yes learning improved. What we did in the class was very good but we drifted away from my emphasis on assessment and exam papers. My feeling is that they drove me on by their engagement and their voices - they were no longer these passive children sitting there".

\section{Student voice and transformation?}

This initial analysis of data from these case-study schools focused on student voice in the classroom from the perspective of dialogue, interaction and communication and then from the perspective of students 'having a say' in what happened in that class. A further deeper analysis will look at the student council, and at the potential for student voice in 
the classroom to co-construct and transform classroom practice, atmosphere, relationships and students' learning.

From mapping and navigating the surface of this student voice landscape, it was clear that there was no variation in the results arising from the initial data analysis in relation to school type. Students in all three schools demonstrated an ability to think about and analyse their experience in classrooms. The teachers were reflecting on their practice, on the context of their school and classroom, and on the pressures of curriculum and assessment. The students raised issues of pedagogy, of relationship, of engagement and participation, and on how they learned in classroom settings. The teachers discussed how particular subject areas, the age of their students and particular programmes and cycles in schools could affect their engagement with student voice. Classroom management, streaming or mixed-ability classroom organisation and leadership at class and whole-school level were also present on this student voice landscape.

In the bedrock of this landscape however, lie issues of curriculum ideology, of power, of trust, of relationship, and of the traditional and authoritative positioning of the teacher in the classroom. Student voice presents the challenge of bringing these to the surface to allow for the possibility of the transformation and co-construction of classroom practice and students' learning.

Domnall Fleming is a PhD student in the School of Education, under the supervision of Dr. Mary Horgan, Director, Early Years and Childhood Studies, School of Education, UCC. 